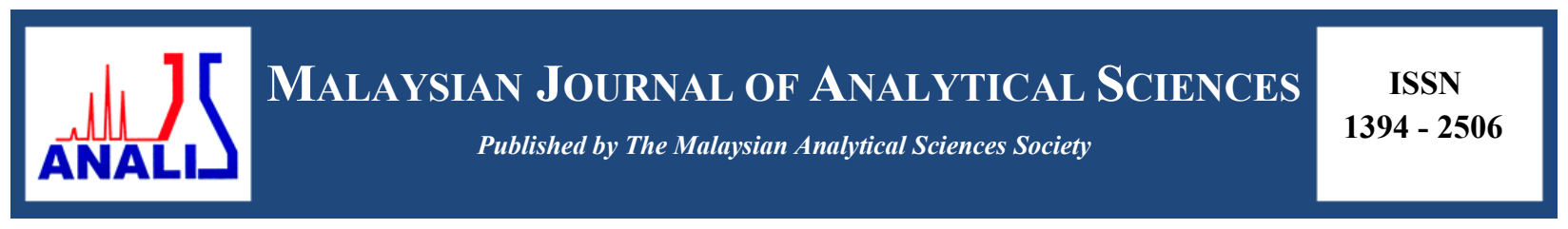

\title{
EFFECT OF MULTI WALLED CARBON NANOTUBES ON THERMAL CONDUCTIVITY OF POLYLACTIC ACID NANOCOMPOSITE
}

\author{
(Kesan Penambahan Nanotiub Karbon Berbilang Dinding Ke Atas Kekonduksian Terma \\ Polilaktik Asid Nanokomposit)
}

\author{
Adilah Mat Ali ${ }^{1}$, Sahrim Hj Ahmad ${ }^{1}$, Mou'ad A.Tarawneh ${ }^{2}$ \\ ${ }^{I}$ School of Applied Physics, Faculty of Science and Technology, \\ Universiti Kebangsaan Malaysia, 43600 UKM Bangi, Selangor, Malaysia \\ ${ }^{2}$ Department of Physics, Collage of Science, \\ Al-Hussein Bin Talal University, P.O. Box 20, Ma'an, Jordan \\ *Corresponding author: sahrim@ukm.edu.my
}

Received: 10 June 2015; Accepted: 21 July 2016

\begin{abstract}
Multi walled carbon nanotubes (MWCNT) hold the increasing interest in many different fields. To employ MWCNT as an effective reinforcement in order to enhance the thermal conductivity of polylactic acid (PLA) modified with liquid natural rubber (LNR), proper dispersion and appropriate interfacial adhesion between MWCNT and PLA/LNR have to be guaranteed. This paper used ultrasonic technique as the method to help to improve the dispersion of MWCNT in PLA/LNR matrix. The result shown that the sample with $3.5 \mathrm{wt} \%$ of MWCNT provided higher thermal conductivity which is believe to be the optimum loading due to better dispersion of MWCNT in PLA/LNR matrix. The $4 \mathrm{wt} \%$ of MWCNT shows decreasing of thermal conductivity due to the presence of agglomeration of MWCNT. The results confirmed by Scanning Electron Microscopy (SEM) micrograph. Fourier Transform Infrared (FTIR) spectra shown that there were no chemical changes happen.
\end{abstract}

Keywords: polylactic acid, multi-walled carbon nanotubes, thermal conductivity, nanocomposites, ultrasonic

\section{Abstrak}

Tiub karbon berbilang dinding (MWCNT) telah menarik minat dalam pelbagai bidang yang berbeza. Bagi memastikan MWCNT dapat digunakan secara berkesan sebagai agen pengukuh dalam peningkatan kekonduksian terma polilaktik asid (PLA)/ cecair getah asli (LNR) nanokomposit, serakan dan lekatan antara muka yang sempurna dan baik di antara MWCNT dan PLA/LNR adalah di antara aspek yang perlu diberi perhatian. Di dalam kertas ini, teknik ultrasonik telah digunakan bagi memastikan membantu penyerakan MWCNT di dalam PLA/LNR matrik. Keputusan menunjukkan sampel yang mengandungi $3.5 \mathrm{wt} \%$ MWCNT menghasilkan kekonduksian terma yang tertinggi dengan pencapaian nilai kandungan optima disebabkan oleh serakan yang baik di dalam PLA/LNR matrik. Pada kandungan MWCNT 4 wt\%, kekonduksian terma menunjukkan penurunan disebabkan oleh gumpalan MWCNT. Keputusan disahkan oleh Imbasan Elektron Microskopi (SEM) mikrograf. Spektra Fourier Transform Inframerah Spektroskopi (FTIR) pula menunjukkan tiada perubahan kimia yang berlaku.

Kata kunci: polilaktik asid, tiub karbon berbilang dinding, kekonduksian terma, nanokomposit, ultrasonik

\section{Introduction}

Recently, carbon nanotube (CNT) has been widely explored and gains much attention to be used as filler in polymer due to their ability to transform an insulating polymer matrix to a conductive composite. CNT developed in 1990s and available as single wall (SWCNT), double wall (DWCNT) and multi wall (MWCNT) [1]. CNT has unique 
structure which enables to be filled with polymer and have low percolation threshold concentration $[2,3]$. CNT not only helps in enhancing in terms of tensile modulus, tensile strength, toughness, glass transition temperature, electrical conductivity but also the thermal conductivity of the polymer composites due to outstanding aspect ratio. CNT incorporated in polymer show thermal conductivity enhancement even at very low loading by forming percolating network. However, it is controlled by many factors such as aspect ratio, dispersion and its interfacial interactions with the polymer matrix.

Even after a decade of research, the potential of employing CNT as reinforcements has become limited because of the difficulties to get good dispersion of CNT during processing and poor interfacial interaction between CNT and polymer matrix. CNT has small diameter in nanometer scale with high aspect ratio $(>1000)$ and extremely large surface area which make the nature of dispersion of CNT differ from other conventional fillers like carbon fibers or spherical particles [1]. Therefore, the basis of CNT dispersion method is introduced here which is ultrasonication which is the most frequently used method for nanoparticle dispersion. This is the method where ultrasound energy is applying in order to agitate particles in the solution by using either an ultrasonic bath or an ultrasonic probe (also known as sonication) [1]. This method is an effective method to disperse CNT in liquids having low viscosity such as water, ethanol and toluene.

In this study, polymer nanocomposites were prepared from biodegradable polymer which is polylactic acid (PLA) with modification using liquid natural rubber (LNR) in order to reduce the brittleness of PLA and filled with MWCNT. The optimal LNR content in the blend was found to be $10 \mathrm{wt} \%$ where it shows it has improve the brittleness and crystallization ability of the PLA [4]. MWCNT was mixed with LNR using ultrasonication method before melt blended with PLA. According to Adilah and Sahrim [5], the tensile strength and Young's modulus of the PLA/LNR/MWCNT nanocomposites which prepared using ultrasonic method shows an improvement compared to the manual method of mixing LNR with MWCNT. The optimum time of ultrasonication was found to be at 1 hour [6]. Thermal conductivity of the polymer nanocomposites produced is discussed in detail.

\section{Materials}

\section{Materials and Methods}

Polylactic acid of Natureworks IngeoTM Biopolymer 3251D grade supplied by Unic Technology Ltd, China was used as the base polymer matrix. It has a density of $1.24 \mathrm{~g} / \mathrm{cm}^{3}$ and melt flow index of $30-40 \mathrm{~g} / 10$ minutes $\left(190^{\circ} \mathrm{C} / 2.16 \mathrm{Kg}\right)$ with melting temperature between $188-210^{\circ} \mathrm{C}$. MWCNT is manufactured by Nanocyl ${ }^{\mathrm{TM}}$ having average diameter of $9.5 \mathrm{~nm}$, carbon purity of $90 \%$ and surface area of $250-300 \mathrm{~m}^{2} / \mathrm{g}$. Figure 1 show the MWCNT used in this paper. LNR was produced by using photochemical sensitized degradation technique. NR of SMR L grade which supplied by Malaysian Rubber Board were immersed in toluene and exposing it to ultraviolet radiation for 6 hours.

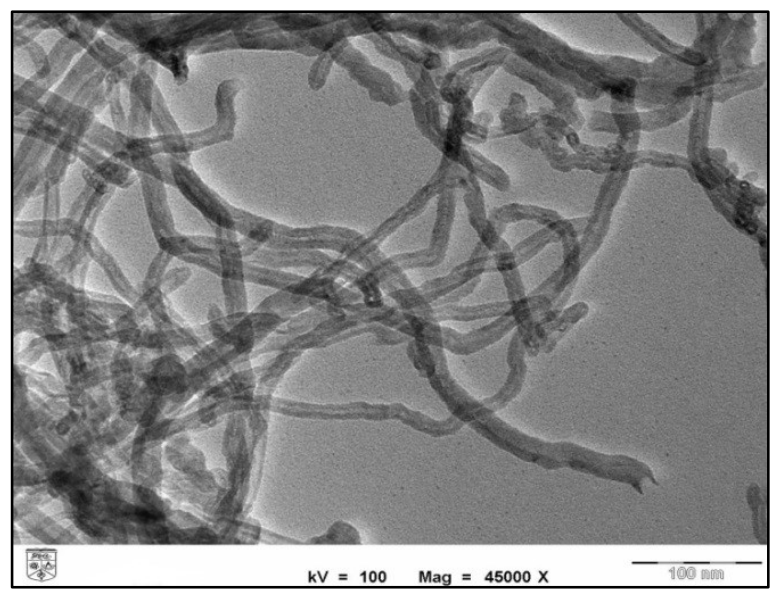

Figure 1. TEM image of pure MWCNT 


\section{Preparation of PLA/LNR/MWCNT nanocomposites}

PLA/LNR/MWCNT nanocomposites were prepared using melt blending using Haake Rheomix internal mixer. The processing parameter is at $190^{\circ} \mathrm{C}$, rotor speed of $90 \mathrm{rpm}$ with 14 mins of mixing time. The LNR concentration was fixed at $10 \mathrm{wt} . \%$. The MWCNT loading was varied at $0.5,1.5,2.5,3.5$ and $4 \mathrm{wt} . \%$. The MWCNT was initially dispersed in the LNR by ultrasonic for 1 hour before melt blended with PLA.

\section{Characterizations of PLA/LNR/MWCNT nanocomposites}

To study the effect of MWCNT filler on thermal conductivity of PLA/LNR nanocomposites, the temperature was varied from $30{ }^{\circ} \mathrm{C}$ to $180{ }^{\circ} \mathrm{C}$ using thermal conductivity analyzer brand NETZSCH and model number LFA 44712 41. The samples used are in disc type having diameter of $12.7 \mathrm{~mm}$ and $1 \mathrm{~mm}$ in thickness. The Fourier Transform Infrared (FTIR) spectroscopy analysis was carried out on Perkin Elmer spectrum V-2000 spectrometer. The samples were scanned between 700 to $4000 \mathrm{~cm}^{-1}$ wave number. The tensile fractured surfaces of the composite were examined by scanning electron microscope (Philips XL 30).

\section{Thermal conductivity}

\section{Results and Discussion}

The thermal conductivity of a material is dominated by atomic vibration or phonons and electrons. However, for insulating materials, conduction by electrons is generally negligible [1]. Generally, thermal conductivity of polymer/CNT nanocomposites depends on several factors such as the interfacial interactions of the CNT with the polymer matrix, the content and dispersion of the CNT.

From the Figure 2, the PLA/LNR and PLA/LNR with 1.5 wt.\% and 3.5 wt.\% of MWCNT shows the decreasing trend of thermal conductivity with increasing temperature for all samples. This is due to the presence of defects and large boundaries at the interface of MWCNT/matrix which increase the thermal resistivity as the temperature increase. Phonons mean free path also will be lowered because it was hindered by interfacial boundary of the PLA/LNR matrix. Thus it will reduce the thermal conductivity of the polymer nanocomposites. From this it shows that the interfacial interaction will affect the thermal conductivity of the PLA/LNR nanocomposites. However, at 4 $\mathrm{wt} \%$ of MWCNT, the graph shows an increment of thermal conductivity with the increasing temperature. At high content of MWCNT in PLA/LNR, MWCNT will provide large surface area and extended shape of MWCNT which will reduce the crystallization of matrix as the temperature increase $[7,8]$. The large amount of junctions among MWCNT makes the increasing of the thermal conductivity by forming conducting path in the matrix. This shows that the content of MWCNT in matrix will affect the thermal conductivity behavior of the PLA/LNR nanocomposites.

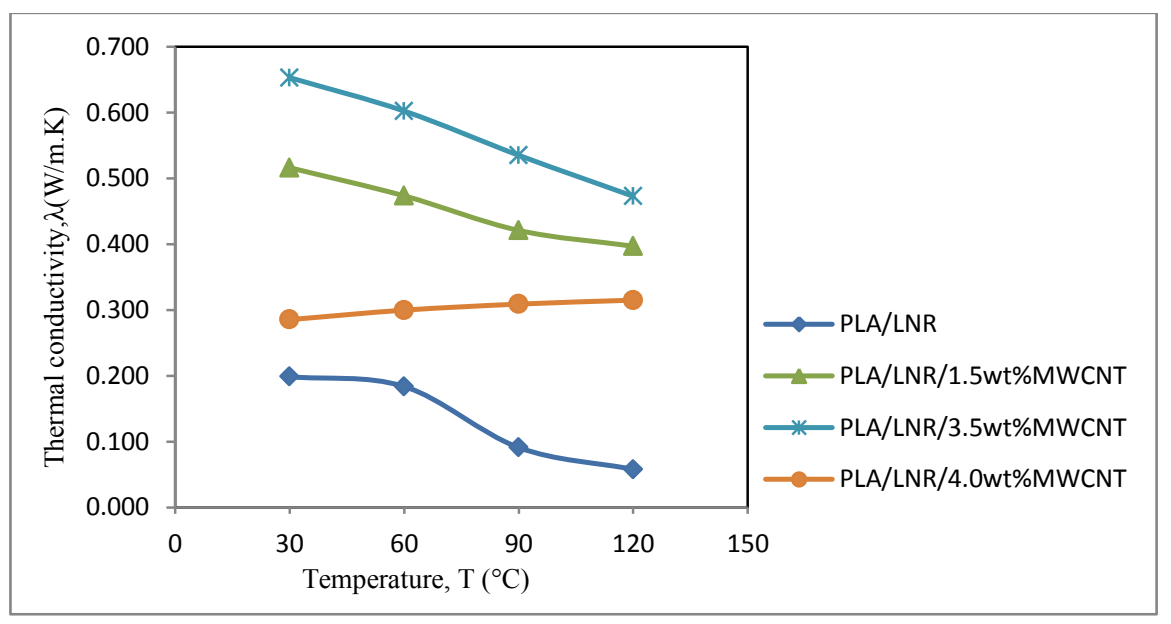

Figure 2. Thermal conductivity dependence of PLA/LNR at different loaded of MWCNT 
Figure 3 it shows of thermal conductivities of PLA/LNR nanocomposites containing 1.5 wt. $\%, 3.5$ wt.\% and 4 wt. $\%$ of MWCNT at $30{ }^{\circ} \mathrm{C}$. It shows remarkable enhancement of thermal conductivity for $1.5 \mathrm{wt} . \%$ and $3.5 \mathrm{wt} . \%$ of MWCNT compared to $4 \mathrm{wt} . \%$ of MWCNT in PLA/LNR. This result obtains due to the presence of highly conductive MWCNT in the PLA/LNR matrix. It provides higher mean free path and higher number of phonons' vibrational modes due to the increasing of crystalline structure. The percolated network of MWCNT inside the PLA/LNR matrix also helps to enhance the thermal conductivity of PLA/LNR nanocomposites. The dispersion of 1.5 wt. $\%$ and 3.5 wt. $\%$ content of MWCNT in PLA/LNR matrix are better than 4 wt.\% of MWCNT as shown in Figure 4. Higher content of MWCNT in the PLA/LNR matrix leads to the reduction of thermal conductivity. This is due to the presence of agglomeration of MWCNT as shown in Fig. 4. The agglomeration of MWCNT will block the phonon travels. This shows that dispersion of MWCNT in matrix plays an important role in enhancing thermal conductivity. From this, the optimum value of thermal conductivity at $30^{\circ} \mathrm{C}$ was achieved by $3.5 \mathrm{wt} \% \%$ of MWCNT content in PLA/LNR. If the MWCNT was added more than this limit, it will give adverse effect to the value of thermal conductivity.

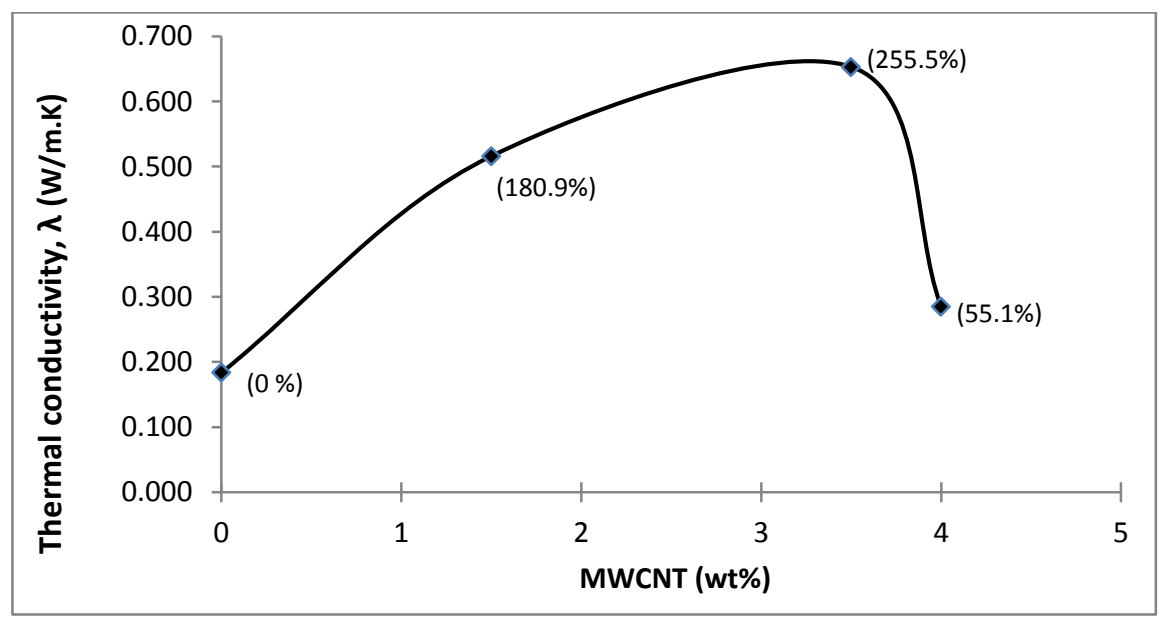

Figure 3. Comparison of thermal conductivities of nanocomposites containing MWCNT with different weight percent at $30{ }^{\circ} \mathrm{C}$ (Data in bracket indicate \% increase in thermal conductivity against the polymer matrix)
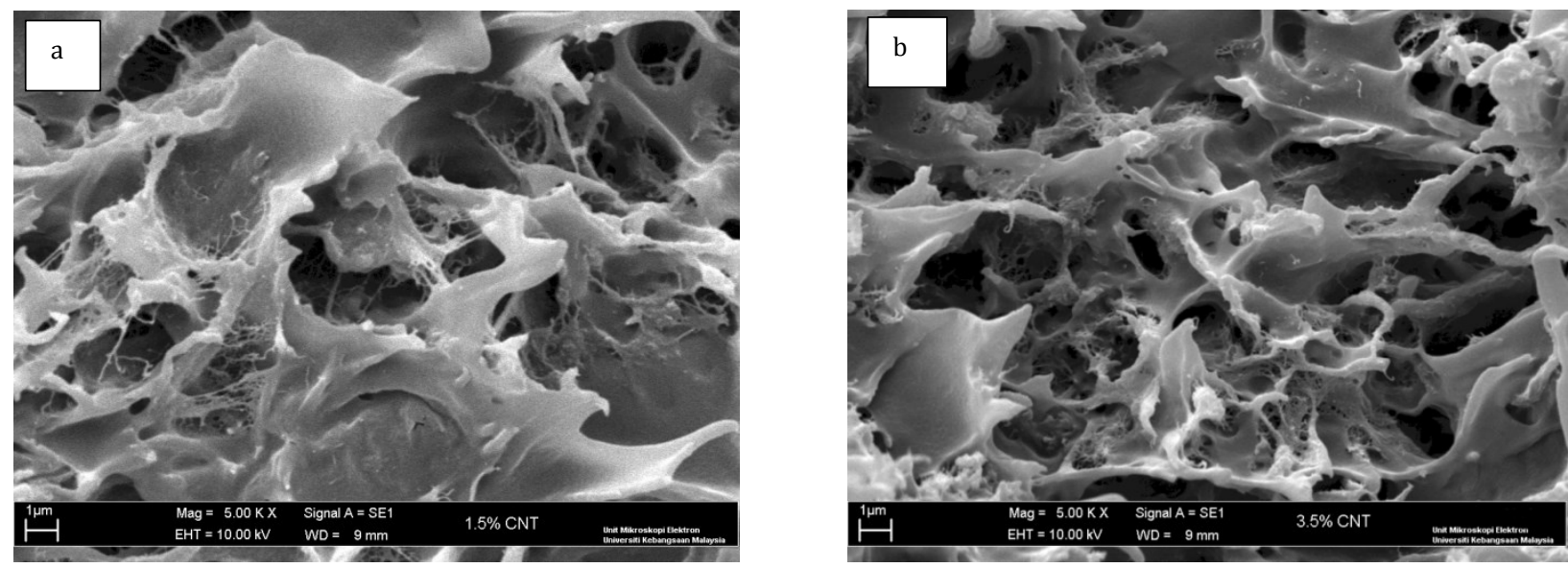


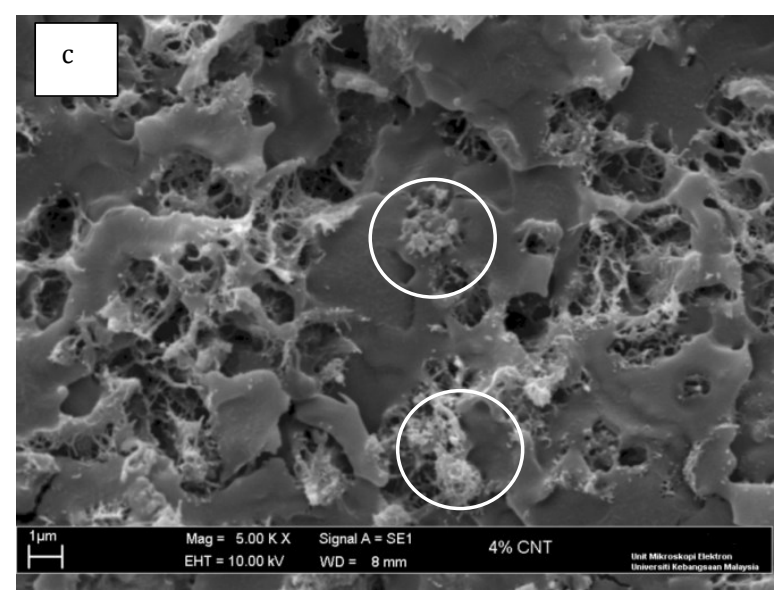

Figure 4. SEM micrograph of a) PLA/LNR at $1.5 \mathrm{wt} \%$ MWCNT b) PLA/LNR at 3.5 wt.\% MWCNT and c) PLA/LNR at 4 wt.\% MWCNT

\section{FTIR analysis}

The FTIR spectra of PLA/LNR and PLA/LNR filled with 3.5 wt.\% of MWCNT are given in Figure 5. The IR bands at 2995 and 2849 which is in the single bond stretch region are assigned to the $\mathrm{C}-\mathrm{H}$ stretch. In the double bond region, the IR band at 1747 is assigned as carbonyl group of $\mathrm{C}=\mathrm{O}$ bond. The peaks at 868 and 755 are related to the amorphous and crystalline region [4]. The peak at 1080 belongs to C-O-C stretching of the PLA. From that figure, it was found that there were no chemical changes happen.

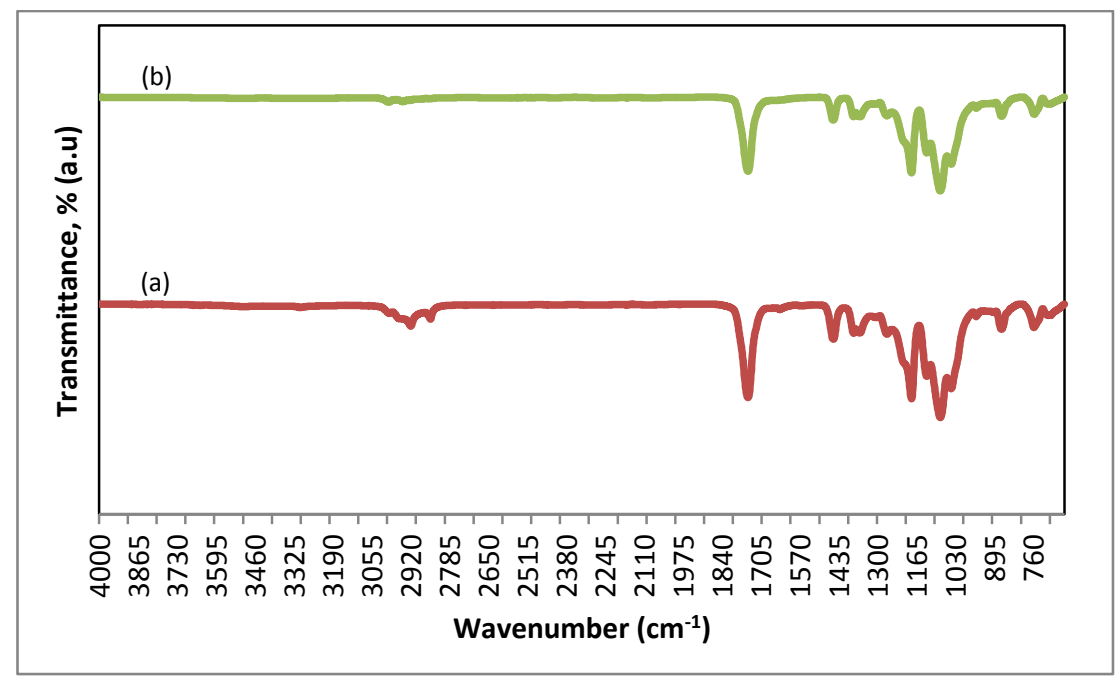

Figure 5. FTIR spectra of a) PLA/LNR and b) PLA/LNR at 3.5 wt.\% of MWCNT

\section{Conclusion}

Conductive polymer nanocomposites was prepared by impregnating PLA/LNR with MWCNT nanoparticles using melt blending technique. SEM micrographs showed good dispersion for $1.5 \mathrm{wt} \%$ and $3.5 \mathrm{wt} . \%$ of MWCNT in PLA/LNR which leads to high thermal conductivity. On the other hand, $3.5 \mathrm{wt} . \%$ of MWCNT sample attained the 


\section{Adilah et al: EFFECT OF MULTI WALLED CARBON NANOTUBES ON THERMAL CONDUCTIVITY OF POLYLACTIC ACID NANOCOMPOSITE}

optimum enhancememt in the thermal conductivity value. FTIR spectra showed that there is no chemical changes occur when PLA/LNR was being added with MWCNT.

\section{Acknowledgement}

The authors would like to thank the National University of Malaysia for sponsoring this research work.

\section{References}

1. Ma, P. C., Siddiqui, N. A., Marom, G. and Kim, J. K. (2010). Dispersion and functionalization of carbon nanotubes for polymer-based nanocomposites: a review. Composites: Part A, 41: 1345-1367.

2. Bonnet, P., Sireude, D., Garnier, B. and Chauvet, O. (2007). Thermal properties and percolation in carbon nanotube-polymer composites. Applied Physics Letter 91: 201910 - 201913.

3. Lu, C. and Mai, Y. W. (2008). Anomalous electrical conductivity and percolation in carbon nanotube composites. Material Science 43(17): 6012 - 6015.

4. Bijarimin, M., Sahrim, A. and Rozaidi, R. (2013). Mechanical, thermal and morphological properties of poly(lactic acid)/natural rubber nanocomposites. Journal of Reinforced Plastics and Composites, 32 (21): 1656 $-1667$.

5. Adilah, M. A. and Sahrim, A. (2013). Effect of processing parameter and filler content on tensile properties of multi-walled carbon nanotubes reinforced polylactic acid nanocomposites. AIP Conference Proceeding 1528: $254-259$.

6. Mou'ad, A., Hafiz, S. A., SeYong, E. and Kin, T. L. (2013). Sonication effect on the mechanical properties of

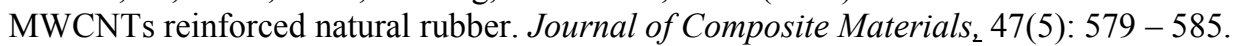

7. Jin, J., Song, M. and Pan F. T. (2007). A DSC study of effect of carbon nanotubes on crystallization behaviour of poly(ethylene oxide). Thermochimica Acta, 45: 25 - 31 .

8. Diez-Pascual A. M., Naffakh M., Gomez M. A., Marco C., Ellis C., Martınez M.T., Anson A., GonzalezDominguez J. M., Martinez-Rubi Y. and Simard B. (2009). Development and characterization of PEEK/carbon nanotube composites. Carbon., 47(13): 3079 - 3090. 